\title{
Compatible Solutes in the Akinetes of the Terrestrial Cyanobacterium Nostoc sp. HK-01 Contribute to Its Heat Tolerance
}

\author{
Shunta Kimura',2, Midori Ong1, Sosaku Ichikawa ${ }^{3}$, Kaori Tomita-Yokotani ${ }^{3}$ \\ ${ }^{1}$ Graduate School of Life and Environmental Sciences, University of Tsukuba, Ibaraki, Japan \\ ${ }^{2}$ Japan Society for the Promotion of Science, Tokyo, Japan \\ ${ }^{3}$ Faculty of Life and Environmental Sciences, University of Tsukuba, Ibaraki, Japan \\ Email: *yokotani.kaori.fn@u.tsukuba.ac.jp
}

How to cite this paper: Kimura, S., Ong, M., Ichikawa, S. and Tomita-Yokotani, K. (2017) Compatible Solutes in the Akinetes of the Terrestrial Cyanobacterium Nostoc sp. HK-01 Contribute to Its Heat Tolerance. American Journal of Plant Sciences, 8, 2695-2711.

https://doi.org/10.4236/ajps.2017.811181

Received: August 31, 2017

Accepted: October 16, 2017

Published: October 19, 2017

Copyright $\odot 2017$ by authors and Scientific Research Publishing Inc. This work is licensed under the Creative Commons Attribution International License (CC BY 4.0).

http://creativecommons.org/licenses/by/4.0/

\begin{abstract}
The detailed mechanisms that facilitate the heat tolerance of terrestrial cyanobacteria have not been completely elucidated, although several reports have revealed aspects of the heat tolerance mechanisms of several other organisms. The dormant cells, called akinetes, of the terrestrial cyanobacterium Nostoc sp. HK-01 can revive after dry heat exposure at $100^{\circ} \mathrm{C}$ for more than $10 \mathrm{~h}$. We investigated the compatible solutes that protect the biomolecules in Nostoc sp. HK-01 akinetes using colonies containing various proportions of akinetes. We extracted the intracellular substances from each colony with $80 \%$ ethanol, which we purified with a series of analytical columns and analyzed by highperformance liquid chromatography and liquid chromatography-electrospray ionization-mass spectrometry. The compatible solutes were screened for their ability to prevent protein aggregation upon heating using the model enzyme lactate dehydrogenase. We detected an accumulation of glucosylglycerol, betaine, and glycine in akinetes. In addition, we confirmed that betaine, glycine, sucrose, and trehalose contributed to the prevention of the protein aggregation. The levels of sucrose and glycine in the colonies were approximately $1000 \times$ higher than those of glucosylglycerol, betaine, or trehalose. Our results indicated that sucrose and glycine are the main compatible solutes in the hydrophilic fractions of the cell extracts of Nostoc sp. HK-01 akinetes.
\end{abstract}

\section{Keywords}

Akinete, Compatible Solute, Cyanobacteria, Dry Heat Tolerance, Nostoc sp. HK-01 


\section{Introduction}

All levels of biological organization are affected by temperature [1]. Many organisms cannot live in high temperature environments as these environments cause damage to the essential macromolecules in their cells [1] [2] [3] [4]. However, some species exhibit either wet or dry heat tolerance.

Wet heat tolerance is the capacity to actively grow in high temperature environments. Hyperthermophile and thermophilic cyanobacteria are well-known wet heat-tolerant species. The archaeal species Pyrolobus fumarii can grow in temperatures up to $113^{\circ} \mathrm{C}$ [5]. The methanogen Methanopyrus kandleri strain 116 can grow at $122^{\circ} \mathrm{C}$ [6]. These organisms have hyperthermophilic mechanisms that stabilize their proteins [7]-[12], DNA [13] [14], and lipid membranes [15] [16]. Several species of thermophilic cyanobacteria are known to grow in temperatures over $50^{\circ} \mathrm{C}$. Synechococcus cf. lividus, Cyanothece cf. minervae, and Thermosynechococcus elongatus $\mathrm{BP}-1$ are cyanobacteria that can grow in geothermal habitats at $73^{\circ} \mathrm{C}-74^{\circ} \mathrm{C}, 62^{\circ} \mathrm{C}$, and $64^{\circ} \mathrm{C}$, respectively [17]. In a previous study of Thermosynechococcus elongatus BP-1, thermal stability of the proteins made it possible to analyze the 3-dimensional structures of photosystems I and II using crystallization methods [18] [19] [20]. Thermophilic cyanobacteria have heat shock proteins (Hsp) [21]. A mutant cyanobacterium that overexpresses a Hsp, Synechococcus sp. PCC 7942, has a high survival rate, photosynthetic electron transport activity, and phycocyanin thermal stability at typically lethal temperatures [22].

Dry heat tolerance is the capacity to survive in high temperature environments, and later revive upon rehydration. Bacillus subtilis, Tardigrades, Polypedilum vanderplanki, and Nostoc are dry heat-tolerant species. Dry B. subtilis colonies, which are in a spore state with low water content, tolerate temperatures from $90^{\circ} \mathrm{C}-120^{\circ} \mathrm{C}$ [3] [23]. The dipicolinic acid and small acid-soluble spore proteins that accumulate in the spores may contribute to the protection of the biomolecules in B. subtilis [3]. The cryptobiotic form of tardigrades, called tun, can revive after exposure to dry heat at temperatures of $90^{\circ} \mathrm{C}-110^{\circ} \mathrm{C}$ [24]. Trehalose, which accumulates as cells adopt a dormant state, contributes to biomolecular protection in tardigrades [25] [26]. Larval Polypedilum vanderplanki in a cryptobiotic state were able to revive after exposure to dry heat at temperatures of $100^{\circ} \mathrm{C}$ [27]. Trehalose and glycerol, which accumulate during the transition of Polypedilum vanderplanki to a cryptobiotic state, may contribute to its biomolecular protection [28]. Dried colonies of the terrestrial cyanobacteria Nostoc flagelliforme and Nostoc commune were able to revive after exposure to dry heat at $85^{\circ} \mathrm{C}$ for $24 \mathrm{~h} \mathrm{[29]} \mathrm{[30]} \mathrm{or} 1 \mathrm{~h} \mathrm{[31],} \mathrm{respectively.} \mathrm{We} \mathrm{previously} \mathrm{reported} \mathrm{that}$ dried colonies of the terrestrial cyanobacterium Nostoc sp. HK-01 were able to revive after exposure to dry heat at $100^{\circ} \mathrm{C}$ for more than $10 \mathrm{~h} \mathrm{[32]} \mathrm{[33].} \mathrm{Howev-}$ er, the detailed mechanisms of heat tolerance among terrestrial cyanobacteria have not been completely elucidated; several reports have partially revealed the 
mechanisms of heat tolerance in other organisms.

Cyanobacteria, which can perform oxygenic photosynthesis, are distributed worldwide in sea water, in fresh water, and on land. The terrestrial cyanobacterium Nostoc sp. HK-01, isolated from Nostoc commune crusts based on its drought tolerance, is capable of photosynthesis, nitrogen fixation, and growth under salted conditions, in environments with poor nutrition, and on Martian regolith simulant; it is also useful as a food [34]-[40]. Furthermore, dried colonies of Nostoc sp. HK-01 have high tolerances to vacuum, ultraviolet (UV), gamma rays, heavy particle beams, and dry heat at a temperature of $100^{\circ} \mathrm{C}$ [32] [33] [37] [40] [41]. Due to its capabilities, Nostoc sp. HK-01 is expected to be the best candidate organism in the future for initial soil formation on bare land and in closed ecosystems in human habitats on Mars [37] [39] [42] [43]. Dried colonies of Nostoc sp. HK-01 are able to grow after exposure to a temperature of $100^{\circ} \mathrm{C}$, although the important pigment chlorophyll degrades above $75^{\circ} \mathrm{C}$ [44]. Dry heat tolerance of temperatures to $100^{\circ} \mathrm{C}$ is remarkable, especially in photosynthetic organisms. Thus, Nostoc sp. HK-01 may have a special mechanism that accounts for its tolerance to dry heat.

The tolerances of terrestrial cyanobacteria to desiccation, $\mathrm{NaCl}$, and $\mathrm{UV}$ are closely linked to extracellular polysaccharides (EPS) [31] [36] [45] [46] [47] [48] [49]. However, the survival rates of Nostoc sp. HK-01 with EPS and without EPS were not markedly different after exposure to $100^{\circ} \mathrm{C}$ of dry heat [33]. This result indicates that the contribution of EPS to the dry heat tolerance of Nostoc sp. HK-01 is likely minimal. Several different types of cells comprise Nostoc sp. HK-01: vegetative cells with photosynthetic abilities, heterocysts with nitrogen fixation abilities, motile hormogonia, and dormant akinetes [32] [33] [34]. Kimura et al. [32] found that only the akinetes in the dry colonies of Nostoc sp. HK-01 are dry heat-tolerant. Those results indicated that the substances that contribute to dry heat tolerance are likely present in akinetes [33]. Akinetes of cyanobacteria are generally larger than other cell types, have a thick cell wall, and accumulate glycogen and granules of cyanophycin [50] [51] [52]. However, the substances that contribute to the environmental tolerances of akinetes have not been elucidated.

The roles of compatible solutes have been thoroughly investigated in the context of several tolerances. Compatible solutes can enhance the stability of a biomolecule during dehydration by forming hydrogen bonds with the polar residues of the biomolecule [53] [54] [55] [56]. They are known to accumulate in cyanobacteria, yeast, bacterial spores, tardigrades, Polypedilum vanderplanki, Artemia, and higher and lower plants [26] [28] [53] [54] [55] [57]-[65]. Various substances act as compatible solutes in different species. In response to dryness, trehalose and sucrose accumulate in cyanobacteria, Phormidium autumnale, Chroococcidiopsis spp., and Anabaena sp. PCC 7120 [57] [63]. However, the types of cells in which those compounds accumulate have not yet been elucidated. In Nostoc sp. HK-01, we previously confirmed the accumulation of sucrose in 
akinetes by quantitative analysis. We used different ratios of akinetes in the colonies in order to verify that selected substances specifically accumulated in akinetes [33]. We also detected trehalose in colonies of Nostoc sp. HK-01, although not specifically in akinetes [33]. It is possible that sucrose and/or trehalose function in akinetes as compatible solutes, but there is no evidence that these compounds contribute to the dry heat tolerance of akinetes. However, there are methods available to identify compatible solutes that prevent protein aggregation and protect enzymatic activity [66] [67] [68] [69].

In this study, we isolated and identified substances that accumulated specifically in Nostoc sp. HK-01 akinetes. We isolated the substances from the hydrophilic layers of cell extracts because compatible solutes, which form hydrogen bonds with biomolecules instead of water, can be categorized as hydrophilic. We tested the biomolecular protective activities of the substances, based on the level of protein aggregation and enzymatic activity in their presence. We used lactate dehydrogenase (LDH), a model enzyme for the measurement of the activity of compatible solutes, for the screening assay [70]. In this report, we describe the mechanism of biomolecular protective activity and the intracellular concentrations of compatible solutes in Nostoc sp. HK-01 akinetes.

\section{Material and Methods}

\subsection{Cyanobacterium and Chemicals}

For all experiments in this study, we used a pure culture of the terrestrial cyanobacterium Nostoc sp. HK-01, stocked at the Ohmori Laboratory (present affiliation; Chuo University) [32] [34].

Betaine, glycine, and sucrose were purchased from Wako (Osaka, Japan). Trehalose was purchased from Tokyo Chemical Industry (Tokyo, Japan). Glucosylglycerol was purchased from Toronto Research Chemicals (Toronto, Canada). Each chemical was dissolved in the buffer for the protein aggregation assay kit, PROTEOSTAT ${ }^{\varpi}$ (Enzo Life Sciences, Farmingdale, New York, USA), to the experimental concentrations.

\subsection{Incubation and Preparation of Colonies}

We prepared dried colonies as described previously [32]. Each group of cells was incubated in the liquid medium BG-11 [71], at $26^{\circ} \mathrm{C}$ with light exposure at 74.3 $\pm 24.3 \mu \mathrm{mol} \cdot \mathrm{m}^{-2} \cdot \mathrm{s}^{-1}$ with a $3-\mathrm{cm}$ amplitude for $120 \mathrm{cycles} \cdot \mathrm{min}^{-1}$ on an SR-1 reciprocating shaker (As One, Osaka, Japan). After incubation, we obtained several groups of wet colonies after counting the cells. The number of total cells and the number of akinetes were counted in photomicrographs taken under a microscope (BX50; Olympus, Tokyo, Japan), using a Thoma counting chamber (Nippon Rinsho Kikai Kogyo, Tokyo, Japan). We calculated the percentage of akinetes in the sample as percentage of akinetes = the number of akinete/the number of all cells $\times 100$. 


\subsection{Analysis of Intracellular Substances by Liquid Chromatography-Electrospray Ionization-Mass Spectrometry}

We extracted the contents of the colonies with different ratios of akinetes with $80 \%$ ethanol at $65^{\circ} \mathrm{C}$. The solutions were concentrated to dryness in vacuo at $38^{\circ} \mathrm{C}$ [63]. The extracts were further purified using a Sep-Pak $\mathrm{C}_{18}$ cartridge (Waters, Milford, Massachusetts, USA) with a water-methanol solvent system, by increasing the methanol concentration in the series from $0 \%$ to $50 \%$ to $100 \%$ (10 $\mathrm{mL}$ per step). The $0 \%$ methanol fraction was purified through a $0.45-\mu \mathrm{m}$ filter (Tosoh, Tokyo, Japan), and each extract was analyzed by liquid chromatography-electrospray ionization-mass spectrometry (LC-ESI-MS). The positive mode of the ESI-MS spectra and several fragments were analyzed with a Waters Micromass ZQ Mass Spectrometer (Waters, Milford, Massachusetts, USA), consisting of an LC 2690 Separation Module with a 996 Photodiode Array and an HPLC/PD detector. The analysis system was used under the following operating conditions: capillary voltage, $3.5 \mathrm{kV}$; cone voltage, $30 \mathrm{~V}$; extractor voltage, $5 \mathrm{~V}$; lens voltage, $0.1 \mathrm{~V}$ RF; source temperature, $120^{\circ} \mathrm{C}$; desolvation gas flow, 300 $\mathrm{L} \cdot \mathrm{hr}^{-1}$; cone gas flow, $50.0 \mathrm{~L} \cdot \mathrm{hr}^{-1}$; column, TSKgel $^{\circledast}$ Amide-80 (particle size, $3 \mu \mathrm{m}$; and dimensions, $2.0 \mathrm{~mm}$ in diameter $\times 15 \mathrm{~cm}$ ) (Tosoh, Tokyo, Japan); column temperature, $30^{\circ} \mathrm{C}$; solvent, $\mathrm{CH}_{3} \mathrm{CN}(80 / 20)$; and flow rate, $0.2 \mathrm{~mL} \cdot \mathrm{min}^{-1}$.

\subsection{Analysis of Intracellular Amino Acids by High-Performance Liquid Chromatography}

We used the AccQ.Tag Amino Acid Analysis Method (Waters, Milford, Massachusetts, USA).We extracted the colonies with the varying ratios of akinetes with $80 \%$ methanol. The solutions were concentrated to dryness in vacuo at $38^{\circ} \mathrm{C}$, as described above. The extracted solutions were acid-hydrolyzed with $6 \mathrm{~N} \mathrm{HCl}$ at $110^{\circ} \mathrm{C}$ for $6 \mathrm{~h}$. The solutions were evaporated to dryness in vacuo at $38^{\circ} \mathrm{C}$ to remove the acid. The extracted water solution that resulted from the acid hydrolysis was further purified through a $0.45-\mu \mathrm{m}$ filter (Tosoh, Tokyo, Japan). The solutions were again evaporated to dryness in vacuo at $38^{\circ} \mathrm{C}$. We added $20 \mu \mathrm{L}$ of $\mathrm{HCl}(20 \mathrm{mM}), 60 \mu \mathrm{L}$ of AccQ Fluor Borate Buffer, and $20 \mu \mathrm{L}$ of AccQ Fluor Reagent (6-aminoquinolyl-N-hydroxysuccinimidyl carbamate) to the solutions. We performed a derivatization of the amino acids in the solutions by heating at $55^{\circ} \mathrm{C}$ for $10 \mathrm{~min}$. The AccQ Fluor Reagent reacts rapidly with primary and secondary amino acids. Each extract was analyzed by high-performance liquid chromatography (HPLC) with a 2695 Separation Module with a 2996 Photodiode Array (Waters, Milford, Massachusetts, USA). The analytical conditions were as follows: column, AccQ.Tag Amino Acid Analysis Column (particle size, $4 \mu \mathrm{m}$; and dimensions, $3.9 \mathrm{~mm}$ in diameter $\times 15 \mathrm{~cm}$ ) (Waters, Milford, Massachusetts, USA); eluted with Eluent A (aqueous buffer), Eluent B (100\% acetonitrile), and Eluent $\mathrm{C}$ (MilliQ water); flow rate, $1.0 \mathrm{~mL} \cdot \mathrm{min}^{-1}$; and detection at 254 $\mathrm{nm}$. The gradient conditions were in accordance with the gradient table in the instruction manual for the AccQ.Tag Amino Acid Analysis Method, starting 
with $100 \%$ Eluent A, followed by $99 \%$ Eluent A to $1 \%$ Eluent B after 0.5 min, 95\% Eluent A to 5\% Eluent B after 18 min, 91\% Eluent A to 9\% Eluent B after 19 min, $83 \%$ Eluent A to $17 \%$ Eluent B after 29.5 min, 60\% Eluent B to $40 \%$ Eluent $\mathrm{C}$ after $33 \mathrm{~min}$, and 100\% Eluent A after 36 min (all ratios are volume per volume).

\subsection{Measurement of Level of Protein Aggregation}

We use a protein aggregation assay kit, PROTEOSTAT ${ }^{\circledR}$ (Enzo Life Sciences, Farmingdale, New York, USA), to measure the extent of protein aggregation. Each sample was mixed with $200 \mu \mathrm{g} / \mathrm{mL}$ LDH (Roche, Berlin, Germany), then heated in an ND-M01 Thermoblock (Nissin, Tokyo, Japan) at $50^{\circ} \mathrm{C}$ for $90 \mathrm{~min}$. We added the PROTEOSTAT ${ }^{\oplus}$ detection reagent (Enzo Life Sciences, Farmingdale, New York, USA), which emits fluorescence when bound to aggregated proteins, to the samples in a 96-well plate. After the samples were kept in the dark for $15 \mathrm{~min}$ at $26^{\circ} \mathrm{C}$, we measured the fluorescence of the samples (excita-

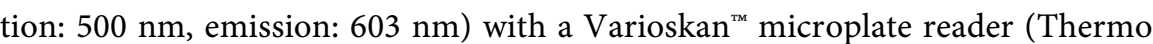
Fisher Scientific, Waltham, Massachusetts, USA).

\subsection{Measurement of Enzymatic Activity}

The Cytotoxicity LDH Assay Kit-WST (Dojindo, Kumamoto, Japan) was used to measure enzymatic activity. We heated $1 \mu \mathrm{g} / \mathrm{mL}$ LDH in an ND-M01 Thermoblock (Nissin, Japan) at $50^{\circ} \mathrm{C}-70^{\circ} \mathrm{C}$ for $0-60 \mathrm{~min}$. We then added $50 \mu \mathrm{L}$ of working solution to $50 \mu \mathrm{L} \mathrm{LDH}$. After the samples were kept in the dark for 30 min at $26^{\circ} \mathrm{C}$, we added $25 \mu \mathrm{L}$ of stop solution. We measured the absorbance ( $\lambda$, $490 \mathrm{~nm}$ ) with a Varioskan ${ }^{\mathrm{Tw}}$ microplate reader (Thermo Fisher Scientific, Waltham, Massachusetts, USA).

\section{Results}

We previously reported that some substances that accumulate in Nostoc sp. HK-01 akinetes could contribute to its heat tolerance as compatible solutes, including sucrose [33]. We isolated and identified substances other than sucrose from the hydrophilic fractions of Nostoc sp. HK-01 cell extracts that accumulated specifically in akinetes. Three candidate compounds, in addition to sucrose, were confirmed in the extracts from the colonies of Nostoc sp. HK-01. We measured the molecular weight of the extracts via the positive mode of LC-ESI-MS. We detected the molecular ions $[\mathrm{M}+\mathrm{Na}]^{+} 277,\left[\mathrm{M}+\mathrm{CH}_{3} \mathrm{CN}+\right.$ $\mathrm{Na}]^{+} 318$, and $[2 \mathrm{M}+\mathrm{Na}]^{+} 532$. These ions were consistent with glucosylglycerol $\left(\mathrm{C}_{9} \mathrm{H}_{18} \mathrm{O}_{8}, 254.23\right)$, and were detected at a retention time of $10.5 \mathrm{~min}$ (Figure 1). The molecular ions $[\mathrm{M}+\mathrm{H}]^{+} 118,[\mathrm{M}+\mathrm{Na}]^{+} 140,[\mathrm{M}+\mathrm{K}]^{+} 156$, and $[\mathrm{M}+$ $\left.\mathrm{CH}_{3} \mathrm{CN}+\mathrm{Na}\right]^{+} 181$, which are specific to betaine $\left(\mathrm{C}_{5} \mathrm{H}_{11} \mathrm{NO}_{2}, 117.15\right)$, were detected at a retention time of $11.7 \mathrm{~min}$ (Figure 2). We analyzed the amino acids in the cell extracts of Nostoc sp. HK-01 by HPLC with the AccQ.Tag Amino Acid Analysis Method. The HPLC peak of glycine was detected at a retention 


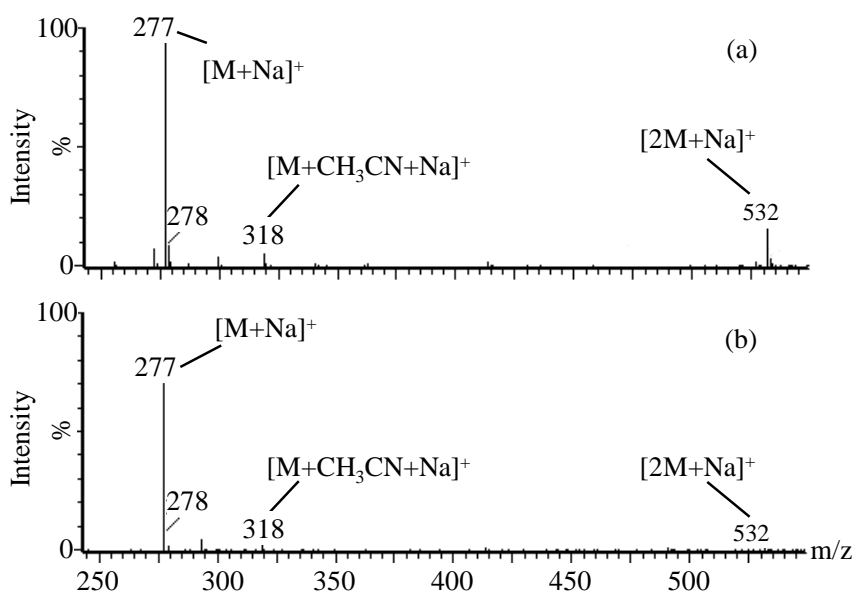

Figure 1. Mass spectra of glucosylglycerol $\left(\mathrm{C}_{9} \mathrm{H}_{18} \mathrm{O}_{8}, 254.23\right)$ and the cell extracts of Nostoc sp. HK-01 analyzed by positive-mode LC-ESI-MS. (a): Glucosylglycerol. (b): Cell extract of Nostocsp. HK-01.
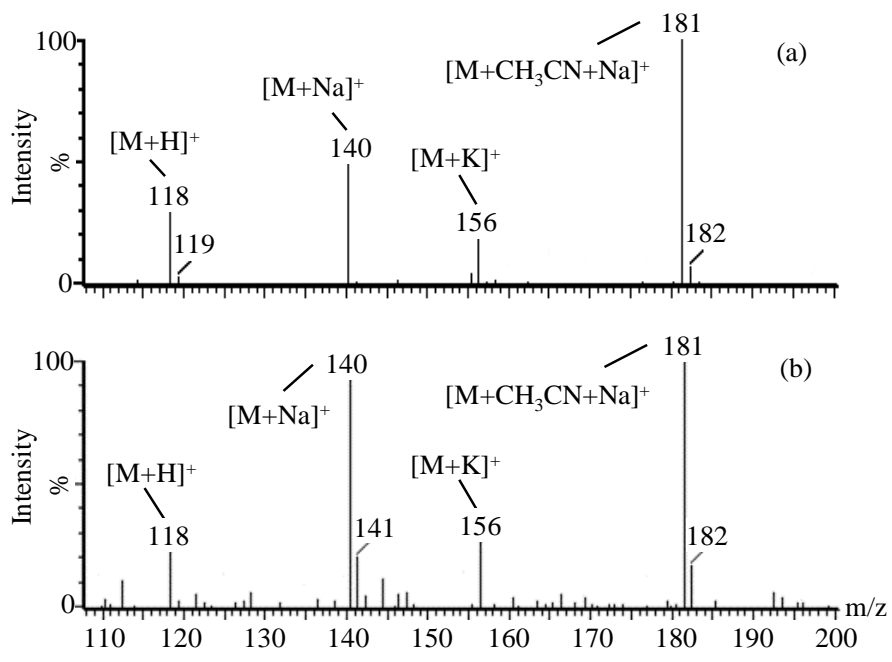

Figure 2. Mass spectra of betaine $\left(\mathrm{C}_{5} \mathrm{H}_{11} \mathrm{NO}_{2}, 117.15\right)$ and the cell extracts of Nostoc sp. HK-01 analyzed by positive-mode LC-ESI-MS. (a): Betaine. (b): Cell extract of Nostoc sp. HK-01.

time of 17.1 - 17.3 min (Figure 3). We performed a quantitative analysis of glucosylglycerol, betaine, and glycine in several colonies with differing akinete content ratios. We detected $0.5 \mathrm{ng}$ glucosylglycerol per $1.0 \times 10^{8}$ cells in a colony with $5 \%$ akinetes and $29.5 \mathrm{ng}$ per $1.0 \times 10^{8}$ cells in a colony with $60 \%$ akinetes (Figure $4(\mathrm{a})$ ). We also detected $5.8 \mathrm{ng}$ betaine per $1.0 \times 10^{8}$ cells in a colony with $5 \%$ akinetes and $17.9 \mathrm{ng}$ per $1.0 \times 10^{8}$ cells in a colony with $60 \%$ akinetes (Figure 4(b)). Glycine was present at $0.3 \mu \mathrm{g}$ per $1.0 \times 10^{8}$ cells in a colony with $5 \%$ akinetes, $8.4 \mu \mathrm{g}$ per $1.0 \times 10^{8}$ cells in a colony with $40 \%$ akinetes, and $8.4 \mu \mathrm{g}$ per 1.0 $\times 10^{8}$ cells in a colony with $75 \%$ akinetes (Figure $4(\mathrm{c})$ ).

The accumulation of sucrose specifically in the akinetes of Nostoc sp. HK-01 has already been reported by Kimura et al. [33]. The presence of trehalose in the colonies has also already been reported, although not specifically in the akinetes 

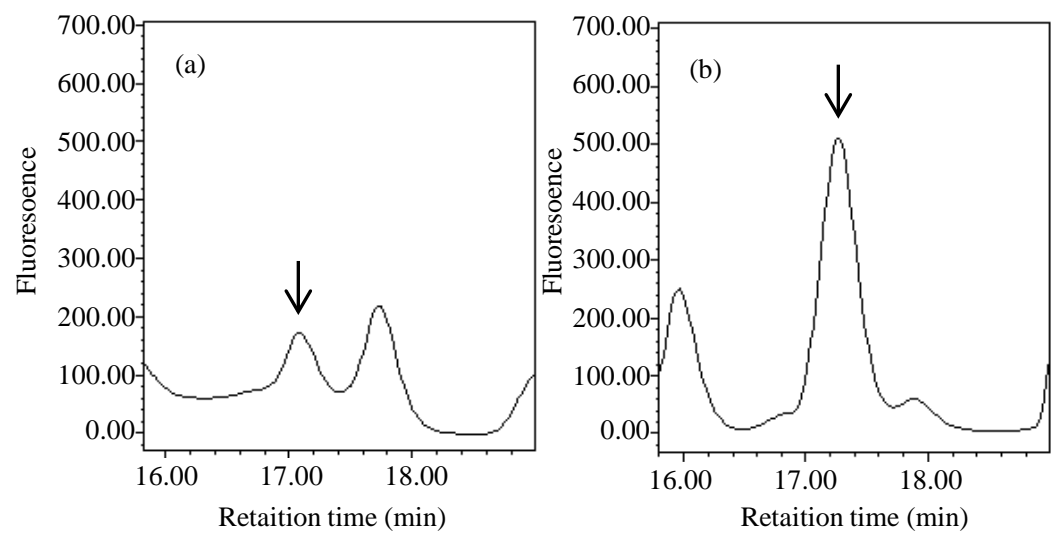

Figure 3. HPLC chromatograms of glycine $\left(\mathrm{C}_{2} \mathrm{H}_{5} \mathrm{NO}_{2}\right.$, 75.07). (a): Standard amino acids. (b): Cell extracts of Nostoc sp. HK-01. Arrows show peaks for glycine.
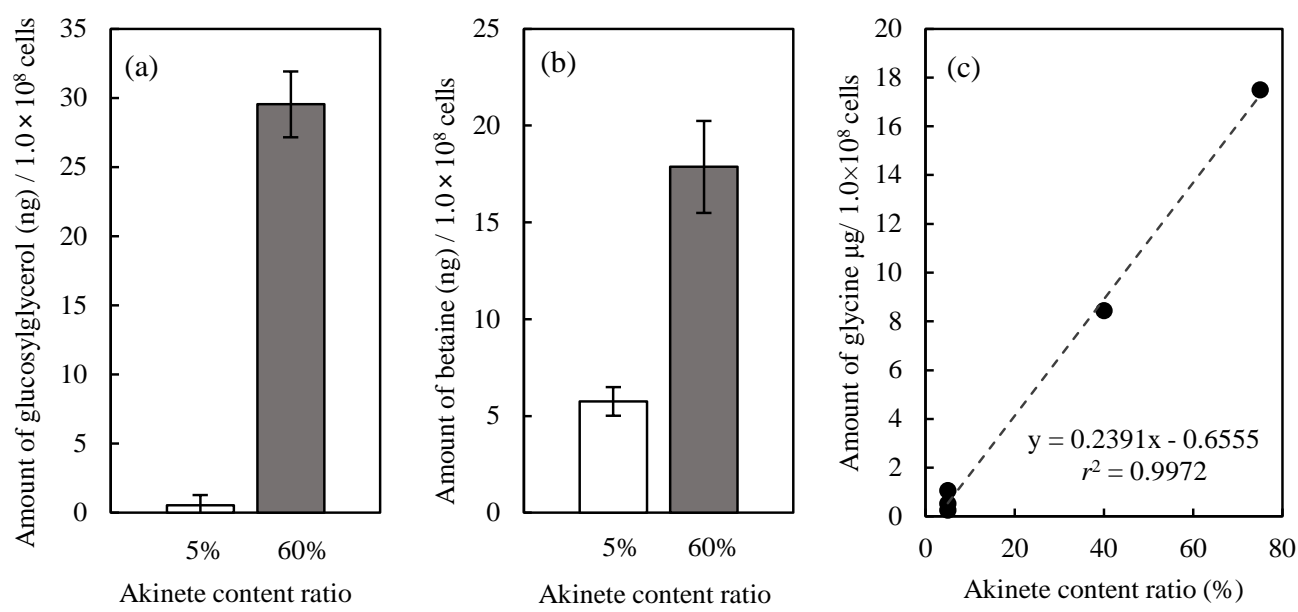

Figure 4. The quantity of the low molecular weight substances per $1.0 \times 10^{8}$ cells in colonies of Nostoc sp. HK-01. (a): glucosylglycerol (ng). (b): betaine (ng). (c): glycine ( $\mu \mathrm{g})$.

[33]. We next tested the activities of glucosylglycerol, betaine, glycine, sucrose, and trehalose for the capacity to prevent protein aggregation in the context of heating. The fluorescence intensity of the control, LDH, with no additives after exposure to heat at $50^{\circ} \mathrm{C}$ for $90 \mathrm{~min}$ was 21.0 . The fluorescence intensities of LDH in the presence of $50 \mathrm{mM}$ and $100 \mathrm{mM}$ glucosylglycerol were 22.2 and 23.8, respectively (Figure 5(a)). The fluorescence intensities of LDH with $50 \mathrm{mM}$ and $100 \mathrm{mM}$ betaine were 18.6 and 14.4, respectively (Figure 5(b)). The fluorescence intensities of LDH with $50 \mathrm{mM}$ and $100 \mathrm{mM}$ glycine were 17.3 and 15.1, respectively (Figure 5(c)). The fluorescence intensity of LDH with $50 \mathrm{mM}$ and 100 $\mathrm{mM}$ sucrose were 13.8 and 12.5, respectively (Figure $5(\mathrm{~d})$ ). The fluorescence intensities of LDH with $100 \mathrm{mM}$ and $250 \mathrm{mM}$ of trehalose were 19.7 and 16.7, respectively (Figure 5(e)). Betaine, glycine, sucrose, and trehalose demonstrated activity against protein aggregation (Figures $5(\mathrm{~b})-(\mathrm{e})$ ), but glucosylglycerol did not (Figure 5(a)). We tested the relationship between the level of protein aggregation and the enzymatic activity of LDH. The enzymatic activities were 79.7\%, $56.8 \%$, and $5.3 \%$ when the fluorescence intensities were 5.7, 7.0, and 23.5, 

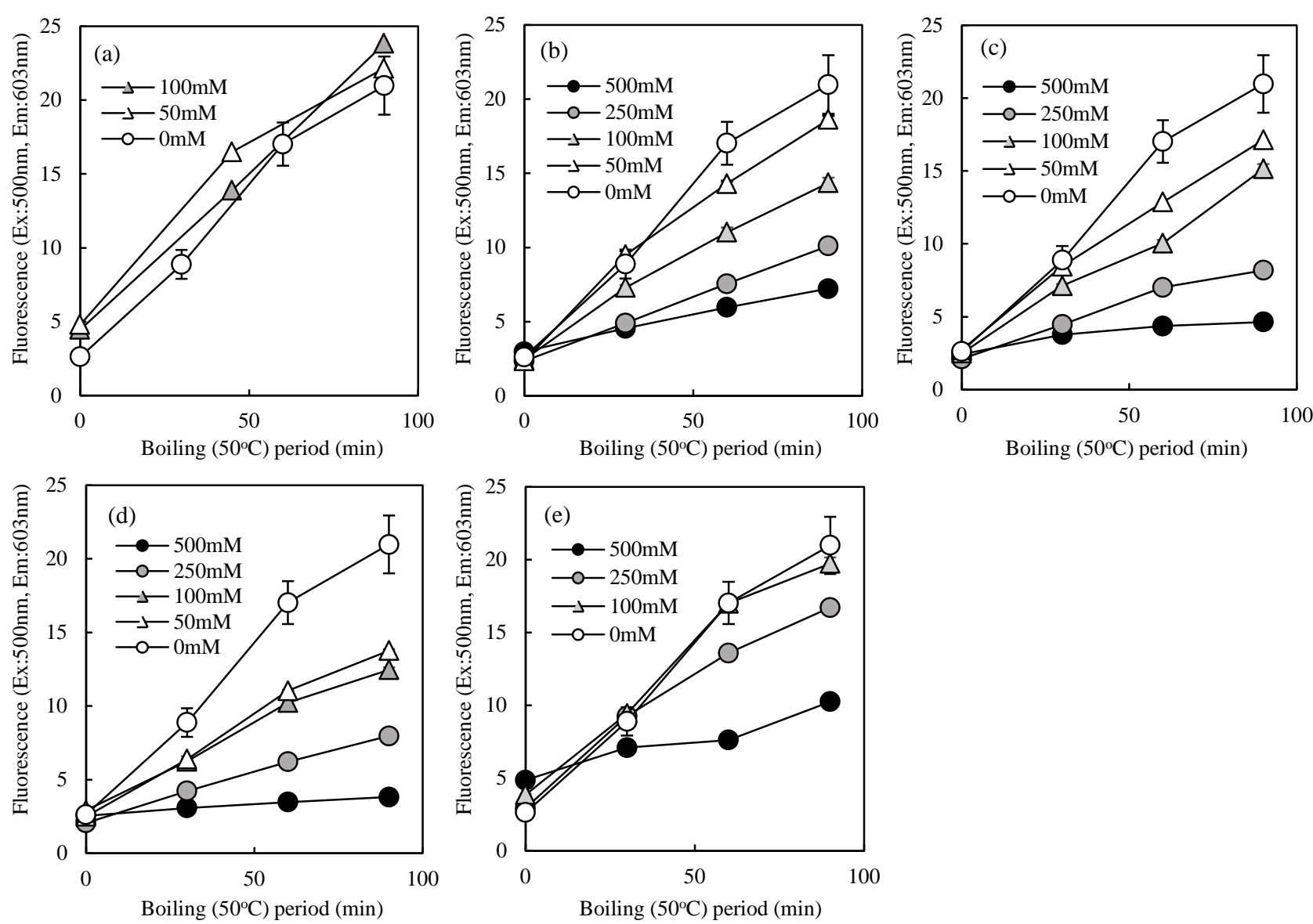

Figure 5. Effects of the substances from the colonies of Nostoc sp. HK-01 on the aggregation of $200 \mu \mathrm{g} / \mathrm{mL} \mathrm{LDH} \mathrm{boiled} \mathrm{at} 50^{\circ} \mathrm{C}$. (a): glucosylglycerol. (b): betaine. (c): glycine. (d): sucrose. (e): trehalose.

respectively, indicating a correlation (Figure $6 ; \mathrm{y}=172.54^{\mathrm{e}-0.133} \mathrm{x}, r^{2}=0.9852$ ).

\section{Discussion}

Our summarized results are shown in Table 1 . The quantities of glucosylglycerol, betaine, and trehalose in the colonies containing a high proportion of akinetes were $30 \mathrm{ng}, 18 \mathrm{ng}$, and $30 \mathrm{ng}$ per $1.0 \times 10^{8}$ cells, respectively. We did not detect protein protective activity by glucosylglycerol. In addition, the accumulation of trehalose was not specific to akinetes [33]. The quantities of sucrose and glycine in the colonies with a high proportion ofakinete were approximately $1000 \times$ higher than those of glucosylglycerol, betaine and trehalose, at $17 \mu \mathrm{g}$ and $18 \mu \mathrm{g}$ per $1.0 \times 10^{8}$ cells, respectively. Thus, our results indicate that sucrose and glycine may be the main compatible solutes among the low molecular weight compounds in the hydrophilic fractions of the Nostoc sp. HK-01 akinetes. We confirmed that sucrose is not only an energy source, but that it also contributes to biomolecular protection in akinetes [33].

The dry state of an Anabaena variabilis akinete contains $2.06 \times 10^{-10} \mathrm{~g}$ of solids and comprises 63\% water [72] [73]. On average, the biomass of an Aphanizomenon ovalisporum (Nostocales) akinete was $0.4 \mathrm{ng}$ (wet weight) [52] [74]. 


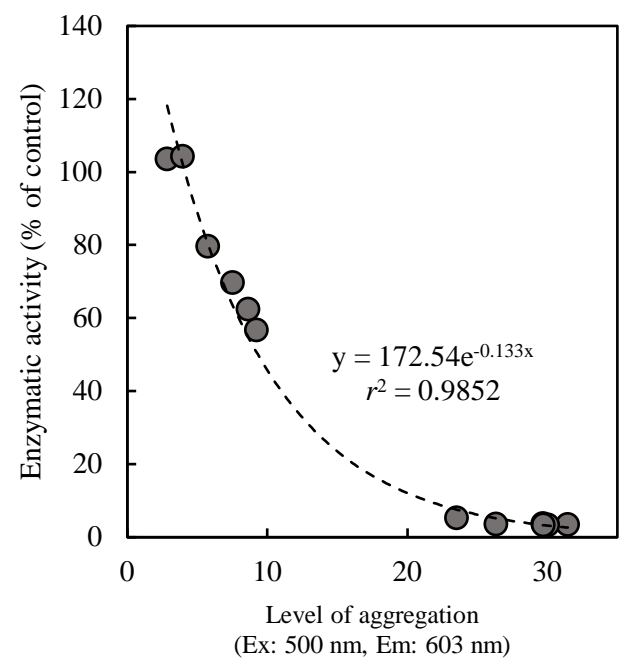

Figure 6. Correlation between enzymatic activity (\% of control) and the level of $\mathrm{LDH}$ aggregation $(\mathrm{n}=12)$.

Table 1. Compatible solutes in akinetes of Nostocsp. HK-01.

\begin{tabular}{|c|c|c|c|c|c|c|}
\hline & $\begin{array}{l}\text { Chemical } \\
\text { formula }\end{array}$ & $\begin{array}{c}\text { Molecular } \\
\text { weight }\end{array}$ & $\begin{array}{l}\text { Amount } \\
/ 10^{8} \text { cells }{ }^{* *}\end{array}$ & $\begin{array}{l}\text { Accumulation } \\
\text { in akinetes } \\
\text { specifically }\end{array}$ & $\begin{array}{c}\text { Protein protect } \\
\text { activity } \\
\text { to heat }{ }^{* * *}\end{array}$ & Structure \\
\hline Glucosyl-glycerol & $\mathrm{C}_{9} \mathrm{H}_{18} \mathrm{O}_{8}$ & 254.23 & $30 \mathrm{ng}$ & + & - & \\
\hline Betaine & $\mathrm{C}_{5} \mathrm{H}_{11} \mathrm{NO}_{2}$ & 117.15 & $18 \mathrm{ng}$ & + & + & \\
\hline Glycine & $\mathrm{C}_{2} \mathrm{H}_{5} \mathrm{NO}_{2}$ & 75.07 & $18 \mu \mathrm{g}$ & + & + & \\
\hline Sucrose & $\mathrm{C}_{12} \mathrm{H}_{22} \mathrm{O}_{11}$ & 342.30 & $17 \mu \mathrm{g}^{*}$ & $+^{*}$ & + & \\
\hline Trehalose & $\mathrm{C}_{12} \mathrm{H}_{22} \mathrm{O}_{11}$ & 342.30 & $30 \mathrm{ng}^{*}$ & $-*$ & + & \\
\hline
\end{tabular}

${ }^{*}$ Data from Kimura et al. 2017 [33]. ${ }^{* *}$ Values from colonies with high akinete content. ${ }^{* * * P r o t e i n ~ p r o t e c t i v e ~ a c t i v i t y ~ t e s t e d ~ b y ~ L D H ~ a g g r e g a t i o n ~ a f t e r ~ h e a t i n g ~}$ $\left(50^{\circ} \mathrm{C}\right)$.

Our data indicated that the dry weight of a Nostoc sp. HK-01 akinete is 0.25 - 0.4 ng (Ong et al., unpublished data). We previously found $0.17 \mathrm{pg}$ sucrose per cell in colonies with $60 \%$ akinetes [33]. In this study, we found $0.18 \mathrm{pg}$ glycine per cell in colonies with $75 \%$ akinetes. Thus, the concentration of sucrose in akinetes would be $2-3.3 \mathrm{mM}$ and the concentration of glycine $9.6-15.8 \mathrm{mM}$, assuming that the water content of a dried akinete is $63 \%$ [73]. The triggers for the differentiation of Nostoc sp. HK-01 vegetative cells to akinetes have not yet been 
identified, although triggers including light intensity, temperature, and the concentration of inorganic nutrients have been reported for other species [50] [51] [74]. We were unable to prepare colonies with $100 \%$ akinetes in this study as the cultures contain many types of cells in various life cell cycle states [33]. Thus, our suggestion that akinetes accumulate higher concentrations of sucrose and glycine is based on the use of colonies with different ratios of akinetes. There is a possibility that the sucrose and glycine concentrations in akinetes were sufficient to protect essential biomolecules.

Several reports have described mechanisms for the prevention of protein aggregation by compatible solutes. Compatible solutes affect the surface tension of proteins [73] [75]. Arginine can prevent protein aggregation through the destabilization of intermediate proteins [75]. Sugars can decelerate the degradation of proteins in the solid state by reducing their mobility via hydrogen bonding [56]. Proteins are denatured when the free energy of the denatured state is lower than the free energy of the native state [76]. Several reports have suggested that protein aggregation can be prevented by the addition of low molecular weight compounds [66] [67] [68] [69] [70] [77]. These compounds might reduce the free energy of the native state, or increase the free energy of the denatured state [76].

We found that the levels of betaine, glycine, sucrose, and trehalose, which are related to heat tolerance, vary between colonies with low akinete contents and high akinete contents (Figures 4(a)-(c); [33]). The accumulation of these compounds could account for the ability of akinetes to tolerate dry heat. The protein protective activities of betaine, glycine, sucrose, and trehalose would have occurred at physiologically optimum concentrations, because each substance could function at different concentrations (Figures 5(a)-(e)). In this study, we demonstrated that the compounds of interest specifically accumulated in akinetes. We identified compatible solutes in Nostoc sp. HK-01 for the first time. The detailed mechanisms of the substances identified will be further investigated in our future studies.

\section{Conclusion}

In this study, we investigated the compounds that were responsible for the dry heat tolerance of Nostoc sp. HK-01. Our findings indicated that sucrose and glycine are the main compatible solutes in the hydrophilic fractions of cell extracts from Nostoc sp. HK-01 akinetes. This exceptional tolerance of Nostoc sp. HK-01 makes it a candidate organism for promoting soil formation on bare land and in closed ecosystems. We believe that our study makes a significant contribution to the literature, because it provides an insight into previously unknown compatible solutes that enable Nostoc sp. HK-01 to survive at temperatures to $100^{\circ} \mathrm{C}$.

\section{Acknowledgements}

The authors thank Prof. Masayuki Ohmori (Faculty of Science and Engineering, Chuo University, Japan) and Dr. Hiroshi Katoh (Life Science Research Center, 
Mie University, Japan) for providing us with a pure culture of the Nostoc sp. HK-01. This work was supported by Grant-in-Aid for JSPS Fellows JP17J00274.

\section{References}

[1] Somero, G.N. (1997) Temperature Relationships: From Molecules to Biogeography. In: Dantzler, W.H., Ed., Handbook of Physiology: Section 13: Comprehensive Physiology Two-Volume Set., Oxford University Press, Oxford, 1391-1444. https://doi.org/10.1002/cphy.cp130219

[2] Akanuma, S., Yamagishi, A., Oshima, T. and Tanaka, N. (1998) Serial Increase in the Thermal Stability of 3-Isopropylmalate Dehydrogenase from Bacillus subtilis by Experimental Evolution. Protein Science, 7, 698-705. https://doi.org/10.1002/pro.5560070319

[3] Setlow, P. (2006) Spores of Bacillus subtilis: their Resistance to and Killing by Radiation, Heat and Chemicals. Journal of Applied Microbiology, 101, 514-525. https://doi.org/10.1111/j.1365-2672.2005.02736.x

[4] Matsuura, Y., Takehira, M., Joti, Y., Ogasahara, K., Tanaka, T., Ono, N., Kunishima, N. and Yutani, K. (2015) Thermodynamics of Protein Denaturation at Temperatures over $100^{\circ} \mathrm{C}$ : CutA1 Mutant Proteins Substituted with Hydrophobic and Charged Residues. Scientific Reports, 5, 1-9. https://doi.org/10.1038/srep15545

[5] Blöchl, E., Rachel, R., Burggraf, S., Hafenbradl, D., Jannasch, H.W. and Stetter, K.O. (1997) Pyrolobus fumarii, gen. and sp. nov., Represents a Novel Group of Archaea, Extending the Upper Temperature Limit for Life to $113^{\circ} \mathrm{C}$. Extremophiles, 1, 14-21. https://doi.org/10.1007/s007920050010

[6] Takai, K., Nakamura, K., Toki, T., Tsunogai, U., Miyazaki, M., Miyazaki, J., Hirayama, H., Nakagawa, S., Nunoura, T. and Horikoshi, K. (2008) Cell Proliferation at $122^{\circ} \mathrm{C}$ and Isotopically Heavy $\mathrm{CH}_{4}$ Production by a Hyperthermophilic Methanogen under High-Pressure Cultivation. Proceedings of the National Academy of Sciences, 105, 10949-10954. https://doi.org/10.1073/pnas.0712334105

[7] Chakravarty, S. and Varadarajan, R. (2000) Elucidation of Determinants of Protein Stability through Genome Sequence Analysis. FEBS Letters, 470, 65-69. https://doi.org/10.1016/S0014-5793(00)01267-9

[8] Maeda, N., Kanai, T., Atomi, H. and Imanaka, T. (2002) The Unique Pentagonal Structure of an Archaeal Rubisco Is Essential for Its High Thermostability. Journal of Biological Chemistry, 277, 31656-31662. https://doi.org/10.1074/jbc.M203117200

[9] Sato, T., Atomi, H. and Imanaka, T. (2007) Archaeal Type III RuBisCOs Function in a Pathway for AMP Metabolism. Science, 315, 1003-1006. https://doi.org/10.1126/science.1135999

[10] Dong, H., Mukaiyama, A., Tadokoro, T., Koga, Y., Takano, K. and Kanaya, S. (2008) Hydrophobic Effect on the Stability and Folding of a Hyperthermophilic Protein. Journal of Molecular Biology, 378, 264-272. https://doi.org/10.1016/j.jmb.2008.02.039

[11] Taylor, T.J. and Vaisman, I.I. (2010) Discrimination of Thermophilic and Mesophilic Proteins. BMC Structural Biology, 10, S5. https://doi.org/10.1186/1472-6807-10-S1-S5

[12] Aono, R., Sato, T., Imanaka, T. and Atomi, H. (2015) A Pentose Bisphosphate Pathway for Nucleoside Degradation in Archaea. Nature Chemical Biology, 11, 355-360. https://doi.org/10.1038/nchembio.1786 
[13] Higashibata, H., Fujiwara, S., Ezaki, S., Takagi, M., Fukui, K. and Imanaka, T. (2000) Effect of Polyamines on Histone-Induced DNA Compaction of Hyperthermophilic Archaea. Journal of Bioscience and Bioengineering, 89, 103-106. https://doi.org/10.1016/S1389-1723(00)88061-5

[14] Atomi, H., Matsumi, R. and Imanaka, T. (2004) Reverse Gyrase Is Not a Prerequisite for Hyperthermophilic Life. Journal of Bacteriology, 186, 4829-4833. https://doi.org/10.1128/JB.186.14.4829-4833.2004

[15] Matsuno, Y., Sugai, A., Higashibata, H., Fukuda, W., Ueda, K., Uda, I., Sato, I., Itoh, T., Imanaka, T. and Fujiwara, S. (2009) Effect of Growth Temperature and Growth Phase on the Lipid Composition of the Archaeal Membrane from Thermococcus kodakaraensis. Bioscience, Biotechnology, and Biochemistry, 73, 104-108. https://doi.org/10.1271/bbb.80520

[16] Boyd, E.S., Pearson, A., Pi, Y., Li, W.J., Zhang, Y.G., He, L., Zhang, C.L. and Geesey, G.G. (2011) Temperature and pH Controls on Glycerol Dibiphytanyl Glycerol Tetraether Lipid Composition in the Hyperthermophilic Crenarchaeon Acidilobus sulfurireducens. Extremophiles, 15, 59-65. https://doi.org/10.1271/bbb.80520

[17] Ward, D.M., Castenholz, R.W. and Miller, S.R. (2012) Cyanobacteria in Geothermal Habitats. In: Whitton, B.A. and Potts, M., Eds., Ecology of Cyanobacteria II, Springer, Dordrecht, 39-63. https://doi.org/10.1007/978-94-007-3855-3_3

[18] Jordan, P., Fromme, P., Witt, H.T., Klukas, O., Saenger, W. and Krauß, N. (2001) Three-Dimensional Structure of Cyanobacterial Photosystem I at $2.5 \AA$ Resolution. Nature, 411, 909-917. https://doi.org/10.1038/35082000

[19] Zouni, A., Witt, H.T., Kern, J., Fromme, P., Krauss, N., Saenger, W. and Orth, P. (2001) Crystal Structure of Photosystem II from Synechococcus elongatus at $3.8 \AA$ Resolution. Nature, 409, 739-743. https://doi.org/10.1038/35055589

[20] Nakamura, Y., Kaneko, T., Sato, S., Ikeuchi, M., Katoh, H., Sasamoto, S., Watanabe, A., Iriguchi M., Kawashima, K., Kimura, T. Kishida, Y., Kiyokawa, C., Kohara, M., Matsumoto, M., Matsuno, A., Nakazaki, N., Shimpo, S., Sugimoto, M., Takeuchi, C., Yamada, M. and Kishida, Y. (2002) Complete Genome Structure of the Thermophilic Cyanobacterium Thermosynechococcus elongatus BP-1. DNA Research, 9, 123-130. https://doi.org/10.1093/dnares/9.4.123

[21] Tanaka, N. and Nakamoto, H. (1999) HtpG Is Essential for the Thermal Stress Management in Cyanobacteria. FEBS Letters, 458, 117-123.

https://doi.org/10.1016/S0014-5793(99)01134-5

[22] Nakamoto, H., Suzuki, N. and Roy, S.K. (2000) Constitutive Expression of a Small Heat-Shock Protein Confers Cellular Thermotolerance and Thermal Protection to the Photosynthetic Apparatus in Cyanobacteria. FEBS Letters, 483, 169-174.

https://doi.org/10.1016/S0014-5793(00)02097-4

[23] Gerhardt, P. and Marquis, R.E. (1989) Spore Thermoresistance Mechanisms. In: Slepecky, R.A. and Setlow, P., Eds., Regulation of Procaryotic Development, American Society for Microbiology, Washington DC, 43-63.

[24] Hengherr, S., Worland, M.R., Reuner, A., Brümmer, F. and Schill, R.O. (2009) High-Temperature Tolerance in Anhydrobiotic Tardigrades Is Limited by Glass Transition. Physiological and Biochemical Zoology, 82, 749-755. https://doi.org/10.1086/605954

[25] Hengherr, S., Heyer, A.G., Köhler, H.R. and Schill, R.O. (2008) Trehalose and Anhydrobiosis in Tardigrades: Evidence for Divergence in Responses to Dehydration. FEBS Journal, 275, 281-288. https://doi.org/10.1111/j.1742-4658.2007.06198.x 
[26] Wełnicz, W., Grohme, M.A., Kaczmarek, Ł., Schill, R.O. and Frohme, M. (2011) Anhydrobiosis in Tardigrades: The Last Decade. Journal of Insect Physiology, 57, 577-583. https://doi.org/10.1016/j.jinsphys.2011.03.019

[27] Hinton, H. E. (1960) A Fly Larva That Tolerates Dehydration and Temperatures of $-270^{\circ}$ to $+102^{\circ}$ C. Nature, $188,336-337$. https://doi.org/10.1038/188336a0

[28] Sakurai, M., Furuki, T., Akao, K.I., Tanaka, D., Nakahara, Y., Kikawada, T., Watanabe, M. and Okuda, T. (2008) Vitrification Is Essential for Anhydrobiosis in an African Chironomid, Polypedilum vanderplanki. Proceedings of the National Academy of Sciences, 105, 5093-5098. https://doi.org/10.1073/pnas.0706197105

[29] Mei, J.X. and Cheng, Z.J. (1990) Effects of Temperature on Physiological Activities of Nostoc flagelliforme Born et Flah. Journal of Northwest Normal University, 1, 75-85. (In Chinese with English Summary)

[30] Gao, K. (1998) Chinese Studies on the Edible Blue-Green Alga, Nostoc flagelliforme: A Review. Journal of Applied Phycology, 10, 37-49. https://doi.org/10.1023/A:1008014424247

[31] Tamaru, Y., Takani, Y., Yoshida, T. and Sakamoto, T. (2005) Crucial Role of Extracellular Polysaccharides in Desiccation and Freezing Tolerance in the Terrestrial Cyanobacterium Nostoc commune. Applied and Environmental Microbiology, 71, 7327-7333. https://doi.org/10.1128/AEM.71.11.7327-7333.2005

[32] Kimura, S., Tomita-Yokotani, K., Igarashi, Y., Sato, S., Katoh, H., Abe, T., Sonoike, K. and Ohmori, M. (2015) The Heat Tolerance of Dry Colonies of a Terrestrial Cyanobacterium, Nostoc sp. HK-01. Biological Sciences in Space, 28, 12-18. https://doi.org/10.2187/bss.29.12

[33] Kimura, S., Tomita-Yokotani, K., Katoh, H., Sato, S. and Ohmori, M. (2017) Complete Life Cycle and Heat Tolerance of Dry Colonies of a Terrestrial Cyanobacterium, Nostoc sp. HK-01. Biological Sciences in Space, 31, 1-8. https://doi.org/10.2187/bss.31.1

[34] Katoh, H., Shiga, Y., Nakahira, Y. and Ohmori, M. (2003) Isolation and Characterization of a Drought-Tolerant Cyanobacterium, Nostoc sp. HK-01. Microbes and Environments, 18, 82-88. https://doi.org/10.1264/jsme2.18.82

[35] Yoshimura, H., Ikeuchi, M. and Ohmori, M. (2006) Up-Regulated Gene Expression during Dehydration in a Terrestrial Cyanobacterium, Nostoc sp. Strain HK-01. Microbes and Environments, 21, 129-133. https://doi.org/10.1264/jsme2.21.129

[36] Yoshimura, H., Kotake, T., Aohara, T., Tsumuraya, Y., Ikeuchi, M. and Ohmori, M. (2012) The Role of Extracellular Polysaccharides Produced by the Terrestrial Cyanobacterium Nostoc sp. Strain HK-01 in $\mathrm{NaCl}$ Tolerance. Journal of Applied Phycology, 24, 237-243. https://doi.org/10.1007/s10811-011-9672-5

[37] Arai, M., Tomita-Yokotani, K., Sato, S., Hashimoto, H., Ohmori, M. and Yamashita, M. (2008) Growth of Terrestrial Cyanobacterium, Nostoc sp., on Martian Regolith Simulant and Its Vacuum Tolerance. Biological Sciences in Space, 22, 8-17. https://doi.org/10.2187/bss.22.8

[38] Kimura, Y., Kimura, S., Sato, S., Katoh, K., Abe, T., Arai, M. and Tomita-Yokotani, K. (2015) Evaluation of a Cyanobacterium, Nostoc sp. HK-01, as Food Material for Space Agriculture on Mars. Biological Sciences in Space, 29, 24-31. https://doi.org/10.2187/bss.29.24

[39] Kimura, Y., Kimura, S., Sato, S. and Tomita-Yokotani, K. (2016) The Function and Utilization of a Terrestrial Cyanobacterium, Nostoc sp. HK-01, as Space Food Eco-Engineering, 28, 43-51. (In Japanese with English Summary) 
[40] Kimura, S., Inoue, K., Katoh, H., Ichikawa, S. and Tomita-Yokotani, K. (2017) Tolerance and Growth of a Terrestrial Cyanobacterium, Nostoc sp. HK-01 under Harsh Environments. Proceedings of the 47 th International Conference on Environmental Systems, ICES-2017-150.

[41] Tomita-Yokotani, K., Kimura, S., Kimura, Y., Igarashi, Y., Ajioka, R., Sato, S., Katoh, H. and Baba, K. (2013) Dried Colony in Cyanobacterium, Nostoc sp. HK-01: The Several High Environment Tolerances for Tanpopo Mission. The International Astrobiology Workshop 2013, Poster Session, 1033.

[42] Katoh, H., Furukawa, J., Tomita-Yokotani, K. and Nishi, Y. (2012) Isolation and Purification of an Axenic Diazotrophic Drought-Tolerant Cyanobacterium, Nostoc commune, from Natural Cyanobacterial Crusts and Its Utilization for Field Research on Soils Polluted with Radioisotopes. Biochimica et Biophysica Acta (BBA) - Bioenergetics, 1817, 1499-1505. https://doi.org/10.1016/j.bbabio.2012.02.039

[43] Verseux, C., Baqué, M., Lehto, K., de Vera, J.P.P., Rothschild, L.J. and Billi, D. (2016) Sustainable Life Support on Mars: The Potential Roles of Cyanobacteria. International Journal of Astrobiology, 15, 65-92. https://doi.org/10.1017/S147355041500021X

[44] Rothschild, L.J. and Mancinelli, R.L. (2001) Life in Extreme Environments. Nature, 409, 1092-1101. https://doi.org/10.1038/35059215

[45] Bertocchi, C., Navarini, N., Cesaro, A. and Anastasio, M. (1990) Polysaccharides from Cyanobacteria. Carbonhydrate Polymers, 12, 127-153. https://doi.org/10.1016/0144-8617(90)90015-K

[46] Ehling-Schulz, M., Bilger, W. and Scherer, S. (1997) UV-B-Induced Synthesis of Photoprotective Pigments and Extracellular Polysaccharides in the terrestrial Cyanobacterium Nostoc commune. Journal of Bacteriology, 179, 1940-1945. https://doi.org/10.1128/jb.179.6.1940-1945.1997

[47] De Philippis, R. and Vincenzini, M. (1998) Exocellular Polysaccharides from Cyanobacteria and Their Possible Applications. FEMS Microbiology Reviews, 22, 151-175. https://doi.org/10.1111/j.1574-6976.1998.tb00365.x

[48] Knowles, E.L. and Castenholz, R.W. (2008) Effect of Exogenous Extracellular Polysaccharides on the Desiccation and Freezing Tolerance of Rock-Inhabiting Phototrophic Microorganisms. FEMS Microbiology Ecology, 66, 261-270. https://doi.org/10.1111/j.1574-6941.2008.00568.x

[49] Mager, D.M. and Thomas, A.D. (2011) Extracellular Polysaccharides from Cyanobacterial Soil Crusts: A Review of Their Role in Dryland Soil Process. Journal of Arid Environments, 75, 91-97. https://doi.org/10.1016/j.jaridenv.2010.10.001

[50] Adams, G.D. and Duggan, S.P. (1999) Tansley Review No. 107. Heterocyst and Akinete Differentiation in Cyanobacteria. The New Phytologist, 144, 3-33. https://doi.org/10.1046/j.1469-8137.1999.00505.x

[51] Kaplan-Levy, R.N., Hadas, O., Summers, M.L., Rücker, J. and Sukenik, A. (2010) Akinetes: Dormant Cells of Cyanobacteria. In: Lubzens, E., Cerdá, J. and Clark, M.S. Eds., Topic in Current Genetics 21; Dormancy and Resistance in Harsh Environments, Springer, Berlin, Heidelberg, 5-27. https://doi.org/10.1007/978-3-642-12422-8_2

[52] Sukenik, A., Maldener, I., Delhaye, T., Viner-Mozzini, Y., Sela, D. and Bormans, M. (2015) Carbon Assimilation and Accumulation of Cyanophycin during the Development of Dormant Cells (Akinetes) in the Cyanobacterium Aphanizomenon ovalisporum. Frontiers in Microbiology, 6, 1067. https://doi.org/10.3389/fmicb.2015.01067 
[53] Crowe, J.H., Carpenter, J.F., and Crowe, L.M. (1998) The Role of Vitrification in Anhydrobiosis. Annual Review of Physiology, 60, 73-103. https://doi.org/10.1146/annurev.physiol.60.1.73

[54] Potts, M. (1999) Mechanisms of Desiccation Tolerance in Cyanobacteria. European Journal of Phycology, 34, 319-328. https://doi.org/10.1080/09670269910001736382

[55] Potts, M. (2001) Desiccation Tolerance: A Simple Process? Trends in Microbiology, 9, 553-559. https://doi.org/10.1016/S0966-842X(01)02231-4

[56] Mensink, M.A., Frijlink, H.W., Van der Voort Maarschalk, K. and Hinrichs, W.L.J. (2017) How Sugars Protect Proteins in the Solid State and during Drying (Review): Mechanisms of Stabilization in Relation to Stress Conditions. European Journal of Pharmaceutics and Biopharmaceutics, 114, 288-295. https://doi.org/10.1016/j.ejpb.2017.01.024

[57] Hershkovitz, N., Oren, A. and Cohen, Y. (1991) Accumulation of Trehalose and Sucrose in Cyanobacteria Exposed to Matric Water Stress. Applied and Environmental Microbiology, 57, 645-648.

[58] Hill, D.R., Peat, A. and Potts, M. (1994) Biochemistry and Structure of the Glycan Secreted by Desiccation-Tolerant Nostoc commune (Cyanobacteria). Protoplasma, 182, 126-148. https://doi.org/10.1007/BF01403474

[59] Blomberg, A. (2000) Metabolic Surprises in Saccharomyces cerevisiae during Adaptation to Saline Conditions: Questions, Some Answers and a Model. FEMS Microbiology Letters, 182, 1-8. https://doi.org/10.1111/j.1574-6968.2000.tb08864.x

[60] Hoekstra, F.A., Golovina, E.A. and Buitink, J. (2001) Mechanisms of Plant Desiccation Tolerance. Trends in Plant Science, 6, 431-438. https://doi.org/10.1016/S1360-1385(01)02052-0

[61] Potts, M. (2000) Nostoc. In: Whitton, B.A. and Potts, M., Eds., The Ecology of Cyanobacteria, Springer, Dordrecht, 465-504.

[62] Elbein, A.D., Pan, Y.T., Pastuszak, I. and Carroll, D. (2003) New Insights on Trehalose: A Multifunctional Molecule. Glycobiology, 13, 17-27. https://doi.org/10.1093/glycob/cwg047

[63] Higo, A., Katoh, H., Ohmori, K., Ikeuchi, M. and Ohmori, M. (2006) The Role of a Gene Cluster for Trehalose Metabolism in Dehydration Tolerance of the Filamentous Cyanobacterium Anabaena sp. PCC 7120. Microbiology, 152, 979-987. https://doi.org/10.1099/mic.0.28583-0

[64] Jönsson, K.I. and Persson, O. (2010) Trehalose in Three Species of Desiccation Tolerant Tardigrades. Open Zoology Journal, 3, 1-5. https://doi.org/10.2174/1874336601003010001

[65] Klähn, S. and Hagemann, M. (2011) Compatible Solute Biosynthesis in Cyanobacteria. Environmental Microbiology, 13, 551-562. https://doi.org/10.1111/j.1462-2920.2010.02366.x

[66] Carpenter, J.F. and Crowe, J.H. (1988) The Mechanism of Cryoprotection of Proteins by Solutes. Cryobiology, 25, 244-255. https://doi.org/10.1016/0011-2240(88)90032-6

[67] Göller, K. and Galinski, E.A. (1999) Protection of a Model Enzyme (Lactate Dehydrogenase) against Heat, Urea and Freeze-Thaw Treatment by Compatible Solute Additives. Journal of Molecular Catalysis B: Enzymatic, 7, 37-45. https://doi.org/10.1016/S1381-1177(99)00043-0

[68] Diamant, S., Eliahu, N., Rosenthal, D. and Goloubinoff, P. (2001) Chemical Chaperones Regulate Molecular Chaperones in Vitro and in Cells under Combined Salt and Heat Stresses. Journal of Biological Chemistry, 276, 39586-39591. https://doi.org/10.1074/jbc.M103081200 
[69] Sawangwan, T., Goedl, C. and Nidetzky, B. (2010) Glucosylglycerol and Glucosylglycerate as Enzyme Stabilizers. Biotechnology Journal, 5, 187-191. https://doi.org/10.1002/biot.200900197

[70] Borges, N., Ramos, A., Raven, N.D., Sharp, R.J. and Santos, H. (2002) Comparative Study of the Thermostabilizing Properties of Mannosylglycerate and Other Compatible Solutes on Model Enzymes. Extremophiles, 6, 209-216. https://doi.org/10.1007/s007920100236

[71] Rippka, R., Deruelles, J., Waterbury, J.B., Herdman, M. and Stanier, R.Y. (1979) Generic Assignments, Strain Histories and Properties of Pure Cultures of Cyanobacteria. Journal of General Microbiology, 111, 1-61.

[72] Braune, W. and Sanke, H. (1979) Interferometric Studies of the Dynamics of Hydration and Dry Matter Content during Light-Dependent Germination of the Anabaena variabilis Kützing Akinetes. Zeitschrift fur Allgemeine Mikrobiologie, 19, 535-546. (In German with English Summary) https://doi.org/10.1002/jobm.3630190803

[73] Potts, M. (1994) Desiccation Tolerance of Prokaryotes. Microbiological Reviews, 58, 755-805.

[74] Sukenik, A., Kaplan-Levy, R.N., Viner-Mozzini, Y., Quesada, A. and Hadas, O. (2013) Potassium Deficiency Triggers the Development of Dormant Cells (Akinetes) in Aphanizomenon ovalisporum (Nostocales, Cyanoprokaryota). Journal of phycology, 49, 580-587. https://doi.org/10.1111/jpy.12069

[75] Tsumoto, K., Umetsu, M., Kumagai, I., Ejima, D., Philo, J.S. and Arakawa, T. (2004) Role of Arginine in Protein Refolding, Solubilization, and Purification. Biotechnology Progress, 20, 1301-1308. https://doi.org/10.1021/bp0498793

[76] Chi, E.Y., Krishnan, S., Randolph, T.W. and Carpenter, J.F. (2003) Physical Stability of Proteins in Aqueous Solution: Mechanism and Driving Forces in Nonnative Protein Aggregation. Pharmaceutical Research, 20, 1325-1336. https://doi.org/10.1023/A:1025771421906

[77] Shiraki, K., Kudou, M., Fujiwara, S., Imanaka, T. and Takagi, M. (2002) Biophysical Effect of Amino Acids on the Prevention of Protein Aggregation. The Journal of Biochemistry, 132, 591-595. https://doi.org/10.1093/oxfordjournals.jbchem.a003261 